Antonio Bentué

Profesor de la Facultad de Teología

Pontificia Universidad Católica de Chile

\title{
Facultad de Teología (70 años). Desafíos a la credibilidad del cristianismo
}

El tema que nos ocupó durante el Seminario del año 2003 fue especialmente "fundamental", en el sentido más clásico de la "teología fundamental". Es la temática de la clásica "demonstratio cristiana": ¿Cuál es la credibilidad de la fe cristiana confrontada a los cuestionamientos provenientes de la cultura de una modernidad progresivamente secularizada y de una mayor conciencia del mundo globalizado, pero a la vez consciente de una diversidad cultural que condiciona sus tradiciones respectivas, incluyendo obviamente las religiosas?

Ahora bien, esa "credibilidad" no puede únicamente fundarse en una fe cristiana comprendida como "don sobrenatural" recibido al margen de los condicionamientos naturales previos; tanto más si la pregunta nos la hacemos desde una perspectiva no calvinista, sino católica que excluye la hipótesis teológica de la "doble predestinación" que le permitiera postular simplemente que aquel a quien les sea dado el "don de la fe" la encontrará creíble y a quien no tenga ese don, no le servirá de nada un discurso humano, por razonable que éste sea. Sin embargo, ya el mismo Agustín postulaba que "Una fe no reflexionada deja de ser fe; ya que nadie puede creer en algo, si antes no ha comprendido que ello debe ser creído" (Fides non cogitata nulla est. Nullus quippe credit aliquid, nisi prius cogitaverit esse credendum; De Praedestinatione Sanctorum, II, 5).

Así, pues, fiel a ese predicamento, el Seminario partió con un status quaestionis presentado por el Prof. Fernando Verdugo, sobre los "criterios de credibilidad", o sea, dónde radica la "calidad de creíble" para una determinada propuesta, así como los condicionamientos culturales en que esos criterios se ubican en la modernidad para la fe cristiana. Y el Prof. Verdugo, siguiendo al Prof. Tornos, centró el problema en la función "identitaria" y "epistemológica" de la cultura misma. Pero, dado que esa "identidad epistemológica" es plural, la percepción de la "credibilidad" del mensaje será también plural, lo cual obligará a la Iglesia a tomar seriamente en cuenta tal identidad epistemológica del receptor de la Palabra transmitida.

Todas las demás ponencias del Seminario se plantearon, de hecho, desde esa perspectiva. Nuestro Vice Gran Canciller y profesor Andrés Arteaga mostró la pertinencia de la fe cristiana a partir sobre todo del aterrizaje de la Palabra hecha por el Vaticano II, como muestra de la "increíble actualidad" del misterio de Cristo. To- 
mando como criterio de pertinencia y, por lo mismo de verdad, el genialmente expresado por Gaudium et Spes, cuando dice: "Con razón podemos decir que el futuro de la humanidad está en manos de quienes sean capaces de transmitir razones para vivir y para esperar a las próximas generaciones" (GS 31). Y el Prof. Arteaga postula que el mensaje cristiano es, en ese sentido, un mensaje "increíblemente actual" debido a su "referencia soteriológica", tal como Dei Verbum lo indica también en su texto clave: "Todo lo que ha sido escrito en la Escritura, lo ha sido por nuestra salvación". Por lo mismo "hoy más que nunca la credibilidad de la revelación se juega en la posibilidad de presentar a Jesucristo como salvador del hombre" (p. 204), mostrando al mismo tiempo ese carácter cristológico en íntima relación con el Dios trinitario, presente, no solo en el designio salvífico pascual, sino en el mismo designio Creador (Creatio ex amore).

El Prof. Ignacio Chuecas, desde una perspectiva exegética, muestra también cómo la credibilidad supone que la Palabra sea percibida por el receptor como un mensaje que aporta sentido a su existencia. Ese es el verdadero órgano de la fe, el "corazón”, según la Biblia. Ese "corazón” es a la vez lo que da al pueblo bíblico los "ojos para ver" cómo Dios está presente "salvando". De ahí la importancia de los "signos" dados por Dios para que, "viéndolos" con evidencia, su presencia salvífica sea "creíble" para el pueblo. Si bien tales "signos" en función de la credibilidad pueden, paradójicamente, prescindir de la "visión", de manera que en lugar de "ver para creer", la credibilidad se funde no en una visión de algo "sorprendente" por su carácter maravilloso (miraculum), sino por el poder mismo del sentido de un acontecimiento vulgar y corriente para quien abre los "ojos de la fe", lo cual permite construir una teología del signo, o del milagro, como teología de la fe. Juan, al concluir que son "Felices quienes sin ver han creído", sitúa la credibilidad en la fuerza del sentido salvífico mismo de la Palabra, más que en "visiones" especiales.

Vinculada a esa ambigüedad propia de los hechos portentosos como si fuera el principal criterio de "credibilidad", nuestro decano y profesor Samuel Fernández agudizó el problema con los sutiles argumentos del antiguo pensador pagano Celso en su Discurso verídico. Precisamente toda su crítica a la credibilidad del cristianismo la centra en la oposición entre la dignidad divina y su eventual mutación en actuaciones diversas en el mundo, rompiendo las reglas necesarias de la naturaleza que el mismo Creador había establecido. La irrupción histórica de Dios en Cristo parece, así, contradictoria con el poder eterno e inmutable de Dios que, en una visión de clara influencia estoica, garantiza el ciclo siempre repetitivo de los mortales: "es necesario que siempre sea lo mismo aquello que fue, que es y que será". Por lo mismo, Celso coincide también con la crítica que Símmaco hará a la pretensión de que pueda ser creíble la novedad radical del cristianismo respecto a las demás religiones para acceder al único Misterio inmutable: "no puede llegarse a un misterio tan grande por un solo camino" (Simmachus, Relationes III, 10).

La reflexión sistemática de la "credibilidad" de la fe cristiana la desarrolló el Prof. Juan Noemi, partiendo del desplazamiento que el problema ha sufrido desde el Vaticano I al Vaticano II, al pasar de los "motivos de credibilidad externos a motivos de credibilidad internos"; o sea, mostrando la credibilidad a partir "de los mismos contenidos de la fe" formulados en los "dogmas" cristianos (p. 258). Noemi es consciente de que hoy día el término mismo "dogma” juega en contra de su credibi- 
lidad. Sin embargo, la tarea que se propone es precisamente recuperar su verdadero significado "creíble" para el hombre actual. Lo cual no deja de ser tarea titánica. Para ello, postula la necesidad de identificar el sentido del dogma con la persona misma de Jesús y, por lo mismo, con el Evangelio. De alguna manera la credibilidad del dogma depende de la evidencia de su relación con el Evangelio; por eso toma la pregunta planteada por Kasper, quien postula también esa "pregunta acerca de la relación entre Evangelio y dogma". Lo cual afecta la credibilidad del cristianismo para el hombre actual y a la vez para que la credibilidad de la fe católica pueda ser reconocida por cristianos de la tradición protestante. Esa credibilidad, Noemi la centra en el carácter "histórico-escatológico" del dogma cristiano, precisamente en la medida en que ese dogma se identifica con la persona de Jesucristo en cuanto verdad dada y heredada, a la vez que buscada y esperada (p. 263). Esa búsqueda y espera (escatológica) constituyen las condiciones del sujeto creyente desde las cuales reconoce la validez creíble de lo dado y heredado o transmitido. Tales condiciones, Noemi las denomina "pro-existenciales de credibilidad"; o sea, la situación desde la cual el sujeto receptor se experimenta como concernido e interpelado por la credibilidad del dogma cristiano. Ahí el Prof. Noemi, por razón de limitación del análisis, se concentra solo en algunas condiciones "pro-existenciales" del creyente chileno, sirviéndose de las conclusiones sobre "Desarrollo humano en Chile 2002", particularmente en su capítulo 5 dedicado a "Los cambios de las identidades y pertenencias religiosas". De ahí destaca el carácter de "individualización" de las personas en que la religión adquiere un nuevo sentido, perdiendo importancia su expresión social e institucional, ya que cada persona selecciona y organiza el sentido subjetivo de la fe recibida. De esta manera, la credibilidad se subjetiviza al privatizarse la construcción de sentido (p. 266). Obviamente esta transformación del receptor creyente chileno plantea nuevos desafíos para la credibilidad del "dogma". Y ahí la Iglesia institucional no puede solo remitirse a la autoridad y al voluntarismo. Noemi concluye, pues, su ponencia, con alguna propuesta provisoria ante el problema. Rechaza la propuesta extraída del mero recurso al positivismo de la Palabra, de tipo luterano o Barthiano, así como la categoría de "paradoja" propuesta por Kierkegaard y después también por Urs von Balthasar. Toma, en cambio, la perspectiva de "correlación" propuesta por Tillich, en una línea más "dialéctica" que paradójica; pero, según lo expresa el mismo Tillich, no en el sentido de la "teología dialéctica" de Barth, que es propiamente una teología de la "paradoja" no-dialéctica. Para ser "dialéctica" debería pasar de ser "paradoja crítica a paradoja positiva". Asumir positivamente la paradoja de la fe dogmática, supone precisamente el discurso razonable, que integre en una sola síntesis la positividad y la negatividad de lo afirmado, o dicho en otros términos, la "identidad de la diferencia", que, para Noemi, constituye la identidad entre el Dios creador y el Dios salvador. Por lo mismo el dogma cristiano se sostiene como creíble en la medida que remite retrospectiva y prospectivamente a la persona de Jesucristo como "unidad de la diferencia de inmanencia y transcendencia" (p. 271).

El Prof. Fredy Parra asumió el desafío de plantear los problemas de la "credibilidad de la Iglesia en América Latina", tomando como punto de partida, sobre todo, el aterrizaje del Concilio en los Sínodos de Medellín y, después, en Puebla y Santo Domingo. De ahí recoge como principal signo eclesial de credibilidad el 
testimonio, personal e institucional. La clave del testimonio está, sin embargo, en la "autenticidad cristiana" de los miembros de la Iglesia, expresada no en la mera vida "privada", sino en relación al mundo y a su historia. Y ahí el Prof. Parra se concentra en la teología de los "signos de los tiempos", como el lugar donde ese testimonio de autenticidad cristiana se juega por parte de la Iglesia. Sin embargo, esos "signos" no son siempre claros e incluso postula una "crisis de legibilidad de los signos", los cuales no son siempre tan rápidamente asimilables a los "acontecimientos temporales", como si estos constituyeran expresión "automática" de la presencia indicativa del Espíritu. Lo cual obliga precisamente a confrontar tales "signos" con el Evangelio de Jesús y la autenticidad de su vivencia cristiana. La ambigüedad de los "acontecimientos" como criterio significativo para la fe creíble hoy en América Latina, lleva a Parra a un largo análisis sobre diversos aspectos a tomar en cuenta para enfrentar esa ambigüedad superando la llamada "omnipotencia del presente" para recuperar auténticamente la "memoria" del pasado histórico, así como la esperanza común de la humanidad. Historia y escatología son dos categorías centrales para Parra, como lo eran también para Noemi.

El Prof. Mario Romero plantea el tema de la credibilidad como problema "pastoral", centrándolo en cuatro aspectos: la comunidad, la comunicación, la misión y la celebración de la fe. La "comunidad" de creyentes que muestren su fe más allá del intimismo "narcisista" y, a la vez, acogedora de los de "fuera", sin que tal comunidad aparezca como un grupo "sectario". La comunicación debe integrar todo lo ya señalado sobre el carácter "razonable" de lo comunicado, así como la "coherencia" de la comunidad eclesial, que es clave para su misión. Finalmente, la "celebración" de la fe constituye la dimensión "festiva" de la fe, que la hace compartible a nivel del "sentimiento" y no solo de la conciencia de lo razonable.

Los profesores Fernando Retamal y Waldo Romo plantearon el tema de la credibilidad por los dos costados más problemáticos hoy día, particularmente para la juventud, como son el "poder" en la Iglesia y la "sexualidad" según el Magisterio de la Iglesia. ¿Es creíble una fe cristiana, transmitida con tanto “poder eclesiástico” y, a la vez, con tanto tabú sobre todo cuanto tenga que ver con el sexo?

El Prof. Retamal enfoca su reflexión aclarando en primer lugar el concepto constantiniano de potestas y la forma como fue asumida y comprendida esa potestas por la Cristiandad. El concepto constantiniano de potestas identificaba en la misma persona del emperador la autoridad civil y la eclesiástica, lo cual será la base de conflictos ulteriores entre poder civil y eclesiástico, así como en la modernidad será un factor, ya sea de crisis de credibilidad de la Iglesia y, como consecuencia, de la fe cristiana que ella vehicula, o bien de utilización de tal poder como sacralizador de intereses de poder sociopolítico de determinados grupos.

Retamal muestra la pertinencia del Derecho canónico de la Iglesia precisamente para evitar ambos peligros de abuso de poder eclesiástico, así como para garantizar la independencia de la Iglesia con vistas a cumplir su misión evangelizadora, única que puede hacerla creíble. En ese sentido, muestra el problema principal del antiguo Código de Derecho Canónico (de 1917), que radicaba en su carácter acumulativo ahistórico y que el nuevo Código, después del Vaticano II, busca superar, integrando aspectos "históricos" tales como la "eclesiología de comunión" y no meramente "jerárquica", así como los que denomina "principios segundos” de la 
Reforma, representados por las categorías propias de los "derechos humanos" de dignidad, libertad, igualdad y pluralismo de todos los fieles en la Iglesia, conjuntamente con la verdadera colegialidad sacramental del episcopado católico, que le permita abrirse ecuménicamente a las demás iglesias (p. 339). En la segunda parte de su ponencia, Retamal desarrolla estas categorías como los criterios fundamentales de la "credibilidad" de la "potestad" de la Iglesia, para el hombre actual.

Finalmente, Waldo Romo presenta el tema "complejo, arduo y ambicioso" (p. 366) que él asumió para el Seminario. El problema sobre la actitud de la Iglesia frente a la "sexualidad" constituye el más decidor para su credibilidad en la actualidad. Y Romo toma ese diagnóstico de alguien tan autorizado como el cardenal Kasper. Busca la explicación posible en la falta de mediaciones culturales de la misma Iglesia, cuando trata de esta temática en su discurso moral, a diferencia de otros tipos de discurso. Sin embargo, si la conciencia del hombre actual, particularmente el joven, queda bloqueada ante esa dificultad de comprensión, la credibilidad general de la fe cristiana se verá afectada. El Prof. Romo intenta a lo largo de su ponencia deshacer los entuertos respecto al "tabú" sexual al confundir esa dimensión del instinto humano con el "pecado". Busca sus raíces en cierto dualismo "agustiniano" que solo valora la sexualidad dentro de la pareja en función de la prole: "para la conservación del orden natural y no para servir el deseo" (p. 386), aun cuando acepte como segundo fin el bonum fidei, en los casos en que no es posible la procreación (ancianos, o parejas que cohabiten sin relación sexual). Y obviamente esa tradición planteará serios problemas para una cultura que valoriza la naturaleza en su dimensión creatural instintiva también y casi, sobre todo, como medio de unión de personas que se aman como tales, en cuerpo y alma, y no solo en función de la procreación. Romo analiza detalladamente la integración de este aspecto en la doctrina moral de la Iglesia, particularmente a partir de Juan XXIII y del Vaticano II. Sin embargo, el problema se replanteó nuevamente con la Encíclica Humanae Vitae de Pablo VI, al optar por la conexión inseparable entre el "significado unitivo y el procreativo de la intimidad conyugal", que el ser humano no puede separar por propia iniciativa. En ese criterio radica la condena de todos los medios artificiales de regulación de la natalidad, así como a fortiori de todo ejercicio de sexualidad fuera de la pareja capaz, al menos en principio, de procrear (homosexualidad); incluso vinculando ese criterio no solo al conjunto de actividad de la vida de la pareja, sino a cada uno de sus actos de unión sexual, en una moral "deontológica", más que "teleológica". Romo atribuye a esta identificación "deontológica" de la moral sexual por parte de la Iglesia una de las dificultades mayores para la credibilidad actual que, cuando se plantea el tema moral, lo hace más bien con criterios "teleológicos".

Aun así, el Prof. Romo considera que es posible ir superando esta impasse a medida que la investigación y el diálogo entre moralistas y otros especialistas en ciencias médicas, en psicología y sociología, ayuden a desbloquear el problema para poder "decir" una mejor verdad acerca del hermoso don que Dios nos ha regalado al constituirnos en "varón o en mujer" (p. 410).

Y aquí termino. Ojalá que estos flashes puedan haber dado una visión de la temática que constituyó el objeto de reflexión sobre los "Desafíos actuales a la credibilidad del Cristianismo" que fue el tema del Seminario de la Facultad durante el año 2003. 